\title{
NEW ENDEMIC EOCENE EQUOIDS FROM THE IBERIAN PENINSULA (WESTERN EUROPE)
}

\author{
AINARA BADIOLA ${ }^{*}, 1$ and MIGUEL-ÁNGEL CUESTA ${ }^{2}$ \\ ${ }^{1}$ Departamento de Ciencias de la Tierra, Área de Paleontología, Facultad de Ciencias, Universidad de Zaragoza, \\ Pedro Cerbuna, 12, E-50009 Zaragoza, Spain, abadiola@unizar.es \\ ${ }^{2}$ Departamento de Geología, Facultad de Ciencias, Universidad de Salamanca, Plaza de los Caídos s/n, \\ E-37008 Salamanca, Spain
}

\begin{abstract}
A new plagiolophine equoid from the Eocene of the Iberian Peninsula, Iberolophus gen. nov., is herein reported. This new genus includes two species: I. arabensis sp. nov. (type species) from the Late Eocene (Headonian) of Zambrana (Araba, Basque Country) and I. jimenezi sp. nov. from the late Middle Eocene (Robiacian) of Mazaterón (Soria, Castilla y León). Iberolophus exhibits an unusual dental pattern that has not yet been reported in any other perissodactyl or ungulate to date. A complete (with P1/p1) and very long non-lophoid premolar series, in which premolars exhibit one (in the earlier members) or two (in the later members) high and pointed cusp(s) anteriorly and a low and long backward extended talon/talonid posteriorly, with a bumpy surface texture, is combined with a typical plagiolophine type lophodont and heterodont molar series. The new taxa are ranked as members of the endemic fauna of the Western Iberian Bioprovince. The latter includes the Eocene sites of the central and western Iberian basins (Duero, Almazán, Oviedo, and Miranda-Trebiño Basins), which have yielded Middle and Late Eocene mammal fossil assemblages (mainly perissodactyls, rodents and primates) which differ from those of the Southern Pyrenean Basins and the rest of Europe. The endemism of the perissodactyl faunas persisted during the Late Eocene in the central and western Iberian basins, on the basis that the perissodactyl fossils from the middle Headonian beds at Zambrana (Miranda-Trebiño Basin) are related to endemic taxa from the late Robiacian beds of the Duero, Almazán, and Oviedo Basins.
\end{abstract}

\section{INTRODUCTION}

From the late Early Eocene to the earliest Oligocene, Europe was an archipelago inhabited by an endemic mammalian fauna, which was clearly different from the contemporary fauna in North America and Asia. Perissodactyls were one of the most abundant Eocene mammalian fauna and consisted of a mainly tapir-like group known as lophiodonts and a horse-like group known as equoids. Many of these European endemic mammals became extinct in the earliest Oligocene synchronously with the appearance of Asian immigrants, in an event named by Stehlin (1909) the "Grande Coupure" (e.g., Brunet, 1977; Prothero, 1985; Hooker, 1992; Blondel, 2001; Hooker et al., 2004).

In the Iberian Peninsula, there was a wide diversity of perissodactyls during the Eocene. A faunal list was included in the last synthesis on Eocene mammal faunas presented at the Paleogene biochronological congress which took place in Montpellier (France) in 1997 (see Antunes et al., 1997). This was subsequently updated by Checa (1997), Cuesta (1999, 2003), and Badiola (2004). The recorded biodiversity of the Iberian Eocene perissodactyls is increasing. Eight new equoid taxa, of which three are new genera, have recently been reported by Badiola et al. (in press). Details of two of these have already been published; one refers to a new genus as Bepitherium jordifusalbae Checa and Colombo, 2004 and the other refers to a new species as Pachynolophus zambranensis Badiola, Pereda and Cuesta, 2005. The other new taxa consist of the unpublished species of Leptolophus Remy, 1965 and Palaeotherium Cuvier, 1804 and two new plagiolophine genera (Badiola, 2004). In this paper, one of the two new equoid genera mentioned previously is described, being represented by two species. The type species comes from the Late Eocene beds at Zambrana (Miranda-Trebiño Basin,

\footnotetext{
*Corresponding author.
}

Araba) and an older species comes from the late Middle Eocene beds at Mazaterón (Almazán Basin, Soria). They exhibit an unusual dental pattern that has not yet been reported in any other perissodactyl or ungulate to date. On the basis of the molar series features, they have been assigned to the Plagiolophinae subfamily Cuesta, 1994a. The new taxa are ranked as members of the endemic fauna of the Western Iberian Bioprovince (see last section).

The Zambrana site is situated near the village of Zambrana (Araba, Basque Country), about $70 \mathrm{~km}$ south of Bilbao. Geologically, the fossiliferous beds, which consist of palustrinelacustrine coal bearing marls and marlstones, are located in one of the oldest lacustrine systems from the Miranda-Trebiño Basin (Basque-Cantabrian Region) (Astibia et al., 2000; Fig. 1A). The depositional setting was a shallow and low-gradient freshwater lake margin with a peripheral swamp (Iriarte et al., 2003). To date, 25 vertebrate taxa have been recovered. They consist of anurans, squamates, chelonians, crocodilians, and mammals, including herpetotheriid marsupials, rodents, carnivores, artiodactyls, and perissodactyls (Astibia et al., 2000; Badiola, 2004; Badiola and Cuesta, 2007a; Badiola et al., 2002, 2005). A primate mandible was recently found during the most recent field work. Perissodactyls consist of seven equoids, of which five (two genera and three species) are new taxa as mentioned above. Zambrana is currently the first Paleogene locality in the Iberian Peninsula to have yielded a fossil mammal assemblage belonging to the MP 18 reference level.

The Mazaterón site is situated near the village of Mazaterón (Soria, Castilla y León) about $40 \mathrm{~km}$ southeast of Soria. Geologically, the grey marls that contain the vertebrate fossils are included within the Mazaterón Formation, which consists of lacustrine-palustrine limestones and marls. It is located in the Almazán Basin, which is situated in the eastern sector of the Duero Basin (Fig. 1B). The depositional setting is a shallow lacustrine system, which was subjected to constant flooding and 


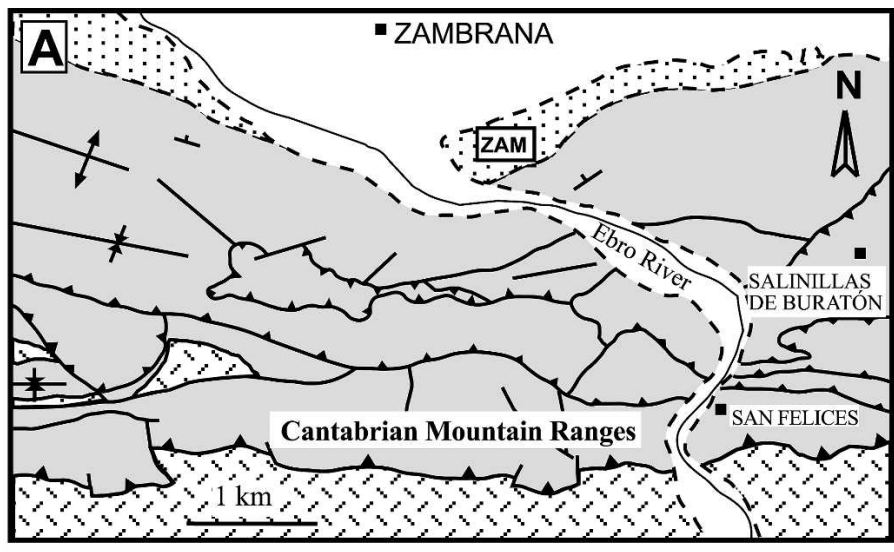

Quaternary

Tertiary

Continental deposits

(Ebro-Rioja Basin)
Cretaceous-Tertiary Marine Deposits

$\because:$ Tertiary

Continental deposits (Miranda-Trebiño Basin)

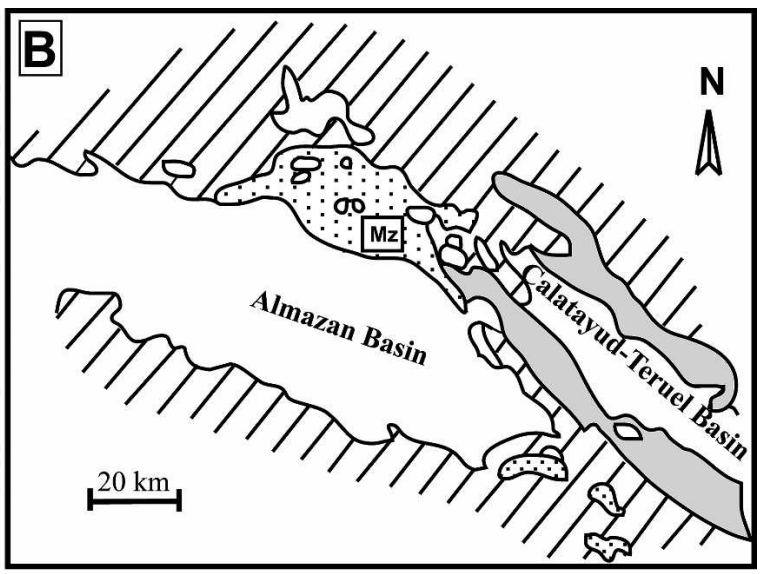

Neogene

Mesozoic

$\because \because$ Paleogene

Paleozoic

ZAM The Zambrana site

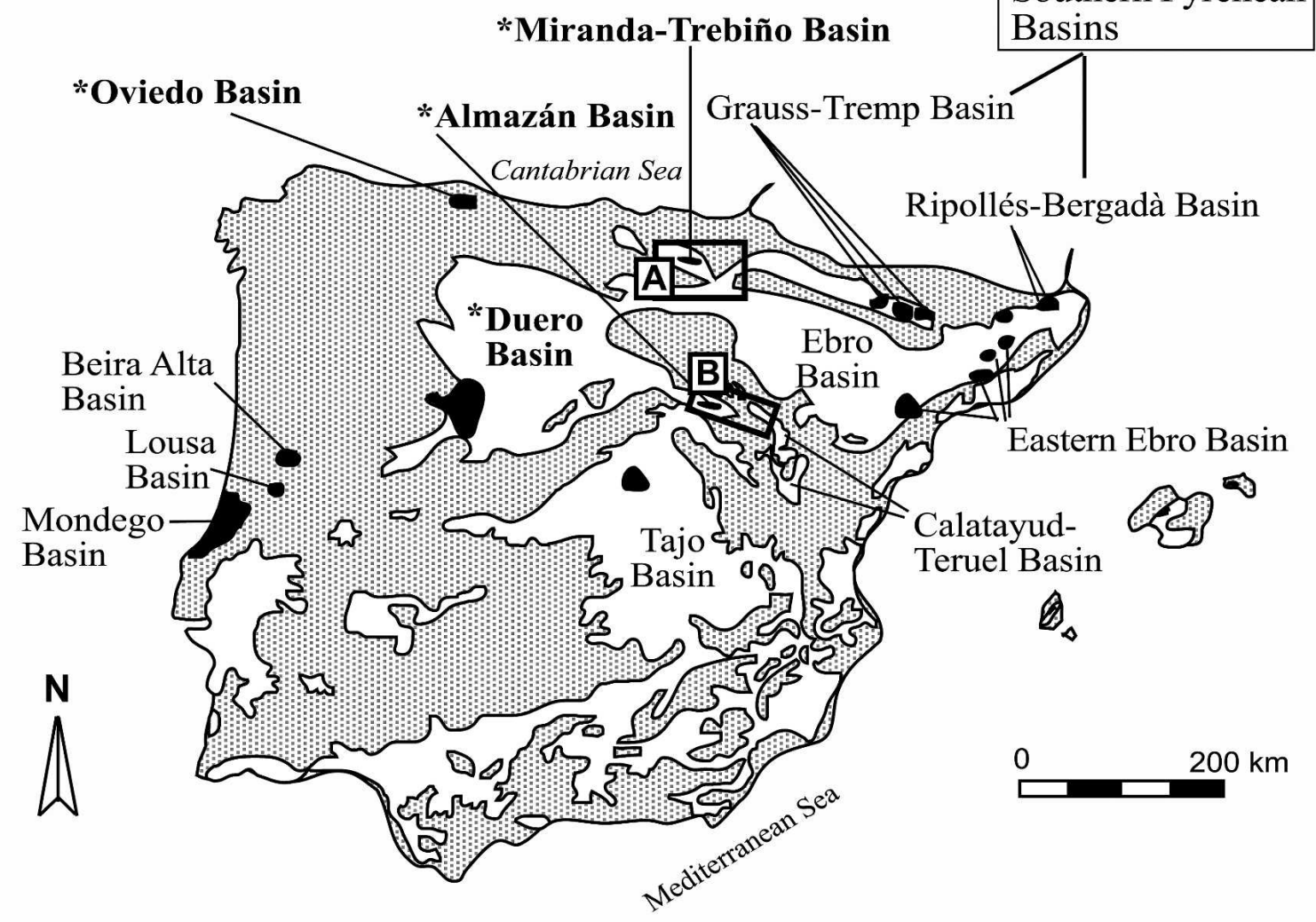

Iberian Tertiary continental basins with $\mathbf{D}$ Eocene mammal sites

FIGURE 1. The main Tertiary continental basins of the Iberian Peninsula with Eocene mammal sites indicated in black. Basins which are included in the Western Iberian Bioprovince are indicated with an asterisk. A list of the Iberian Eocene sites can be consulted in Antunes et al. (1997), Checa (1997) and Badiola et al. (in press: fig. 1). A and B, geological context of Zambrana and Mazaterón sites, respectively (modified from Astibia et al., 2000; and Armenteros, 1994). 
drying processes. For more geological details of the Duero Basin, see Alonso-Gavilán et al. (2004) and for details of the Almazán Basin and its depositional setting, see Huerta and Armenteros (2006) and references therein. To date, 27 Eocene vertebrate taxa, consisting of chelonians, crocodilians and mammals, have been recovered. The mammal fossil assemblage includes rodents, primates, carnivores, artiodactyls and perissodactyls. It is Robiacian (MP 15-16) in age (Cuesta, 1991, 1999; Antunes et al., 1997). The perissodactyl assemblage contains a large lophiodontid and eight equoids (Cuesta, 1991, 1993, 1994a, 1994b, 1994c, 1996). For the summary of other vertebrates from the Duero Basin, see Jiménez (1992) and Cuesta and Jiménez (1994).

Institutional Abbreviations-EHU/UPV, Euskal Herriko Unibertsitatea/Universidad del País Vasco; ANZM/MCNA, Arabako Natur Zientzien Museoa/Museo de Ciencias Naturales de Álava, Vitoria-Gasteiz; NHM, Natural History Museum, London; FPO, Laboratory of Vertebrate Paleontology and Human Paleontology, Université de Poitiers, Poitiers; US, Universidad de Salamanca, Salamanca.

Eocene Locality Abbreviations-From the Iberian Peninsula: In Asturias, LLAM, Llamaquique. In The Basque Country, ZAM, Zambrana. In Castilla y León; CAE, Caenes; CASC, Casaseca de Campeam; CV, Corrales del Vino; DEZ, Deza; FUE, Fuentesaúco; JB, Jambrina; MAZ, Mazaterón; MLP, Molino del Pico; SC, Santa Clara de Avedillo; SM, San Morales; and VS, El Viso-Sanzoles. In Castilla-La Mancha, HU, Huérmeces del Cerro; VJ, Viana de Jadraque. In Catalonia, AG, Ager XII; BA, Les Badies; BFO, Barranc de Forals, BG, Barranc del Guesot; BO, La Boixedat; CA, Capella; CB, Costa de Baró; CC, Can Camperol; CE, Central ENHER; CG, Castigaleu; CH, Chirivieta; CM, La Coma; CMO, Castellnou de Montsec; CO, Corsá; COR, Corral de l'Andreu Nord I\& Sud IV; CP, Can Picatón; EM, Empordá de Terrades; ES, Escarlà; FT, Fet IV; GR, Grauss; GÜ, Güell; Km 86 \& 87 in the Benabarre main road; LI, Litera; LO, Los Olivares; LS, Les Saleres; LV, Les Vinyes; MH, Masia de l'Hereuet; MOL, Molí del Pont; MT, Montderola; MTL, Montllobar; M-2, Camí de la Masia de l'Hereuet; MY, Pont de Montanyana; PM, Sant Pere Martir; PS, Partida de Solà; PU, El Pueyo; RB, La Ribera; RC, La Roca; ROC, Roc de Santa; SB, Sobrenoguera; SJF, Sant Jaume de Frontanyà; SMQ, Sant Miquel; SOS, Sossís; TM, Torre del Moro; TR, Torrelabad; and ULL, Ulldemolins. In Portugal, CôJ, Cojâ; FE, Feligueira Grande; NA, Naia; SI, Silveirinha; and VF, Vale Furado. From Western Europe: In the Quercy Area, RAY, Raynal (Phosphorites du Quercy); PQ, undetermined locality from Phosphorites du Quercy. In Aquitaine, RU, Ruch; SCE, St. Capraise d'Eymet; SO, Soumailles; and VIL, Villebramar. In Auvergne, RO, Ronzon. In Languedoc, EUZ, Euzet-les-Bains; FA, Faveirol, FN, Fons (without F4); and ROB, Robiac. In Provence, LDB, La Débruge; and MR, Murs. In Tarn-et-Garonne, CAS, Castrais. In The Isle of Wight, England, HC, Hordle Cliff. In the Solothurn Canton, Switzerland, EG, Egerkingen. In Baden-Württemberg, Germany, FH, Frohnstetten.

\section{Remarks}

The biochronological scale used in this paper is that of the MP Mammal Paleogene reference levels (Schmidt-Kittler, 1987, updated by Aguilar et al., 1997). These levels are calibrated with respect to the most recent International Stratigraphic Chart and the Eocene European Land Mammal Ages (ELMA: Neustrian, Grauvian, Geiseltalian, Robiacian, and Headonian) (Gradstein et al., 2004). Many and indeed often contradictory systematic propositions for Equoidea Gray, 1821 have been reported (e.g. MacFadden, 1976; Remy, 1976; Franzen, 1989; Hooker 1994; Froehlich, 1999). Here, we do not follow any particular systematic proposition of Equoidea, until a new extensive phylogenetic study can be performed. The new genus herein described is as- signed to the family Palaeotheriidae Bonaparte, 1850 , because all authors to date include the genera Plagiolophus Pomel, 1847a and Palaeotherium and their relatives within this family. However, Cuesta (1994a) classifies only the palaeotheres sensu stricto within Palaeotheriidae, whereas the genera Plagiolophus and Pachynolophus Pomel, $1847 \mathrm{~b}$ and their relatives are included within the family Pachynolophidae Cuesta (1994a). Remy (2004: 168) has challenged the hypothesis of Cuesta (1994a). Plagiolophus and relatives have been assigned to the Plagiolophinae subfamily Cuesta (1994a) or to the Plagiolophini tribe Remy (1976). We include the new genus within the same group of Plagiolophus and relatives, considering it as a plagiolophine equoid.

\section{SYSTEMATIC PALEONTOLOGY}

Order PERISSODACTYLA Owen, 1848

Superfamily EQUOIDEA Gray, 1821

Family PALAEOTHERIIDAE Bonaparte, 1850 IBEROLOPHUS, gen. nov.

Etymology_Plagiolophine equoid from the Iberian Peninsula. Type Species-Iberolophus arabensis sp. nov.

Diagnosis-Medium-sized plagiolophine, characterized by having a complete (with $\mathrm{P} 1 / \mathrm{p} 1$ ) and very long unusual nonlophoid premolar series, combined with a very lophodont and heterodont molar series. Premolars with one (in the earlier members) or two (in the later members) high and pointed cusp(s) anteriorly and with a low and backward extended talon/talonid posteriorly, with a bumpy enamel surface texture. Anterior premolars longer than posterior ones. Upper molars without discrete paraconule and metaconule and with the protoloph and metaloph obliquely oriented to the ectoloph. Thick ribs on the labial side of the parastyle, mesostyle and metastyle. No twinned metaconid in the lower molars and a small hypoconulid is visible in the unworn $\mathrm{m} 1-\mathrm{m} 2$. Large size, hypsodonty and crown outline gradient in the molar series. Thick and sharp cingulum in all premolars, but not continuous in the molars. No cement in the crown of the teeth.

Differential Diagnosis - In addition to the obvious differences with other plagiolophines apparent in the premolar series, Iberolophus gen. nov. can be distinguished from Paraplagiolophus Depéret (1917) in terms of having (1) a more hypsodont, lophodont and heterodont molar series; (2) without discrete paraconule and metaconule and thinner protoloph and metaloph; and (3) a more accentuated size and outline crown gradient in the molar series. From Plagiolophus in having (1) a more lophodont and heterodont molar series; (2) without discrete paraconule in the upper molars; and (3) a more accentuated size and crown outline gradient in the molar series. From Leptolophus in having (1) more brachyodont molars, without a trapezoidal outline in all of them; (2) a thicker protoloph and metaloph; (3) a less flatter ectoloph in the occlusal view; (4) more prominent cingulum; and (5) the absence of cement in the crown of the teeth. From Metaplagiolophus Checa, 1993 in having (1) narrower, more trapezoidal and hypsodont upper molars, with the protoloph and metaloph longer; and (2) a more heterodont molar series, with $\mathrm{M} 3 / \mathrm{m} 3$ considerably larger than $\mathrm{M} 2 / \mathrm{m} 2$.

Included Species-Iberolophus arabensis sp. nov. and Iberolophus jimenezi sp. nov.

Distribution-Late Middle Eocene (late Robiacian) to Late Eocene (middle Headonian), Almazán and Miranda-Trebiño Basins, Iberian Peninsula.

\section{IBEROLOPHUS ARABENSIS, sp. nov.}

(Figs. 2, 3)

Holotype-MCNA 11953, mandible, showing the incisor and canine alveoli, a fragment of the right canine root, and the left $\mathrm{C}-\mathrm{m} 3$ (p1 and $\mathrm{m} 1$ incomplete) and right p3-m3 series. 


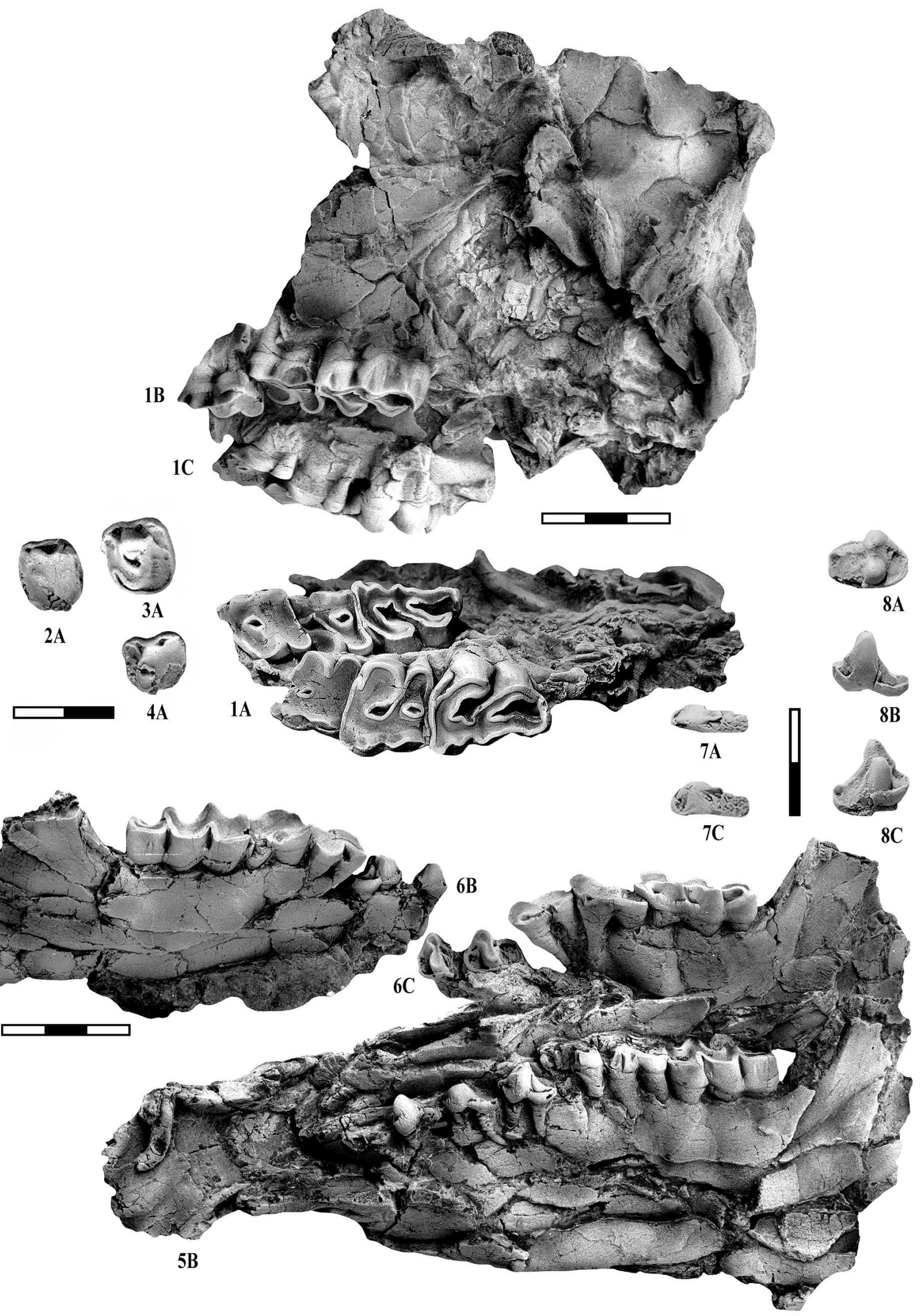


Etymology_After "Araba” / "Álava” (Basque/Spanish bilingual names, respectively), a province of the Basque Country, where the Zambrana site is located.

Type Locality and Horizon-Zambrana (Araba), Iberian Peninsula; Basque-Cantabrian Region, Miranda-Trebiño Basin, middle Headonian (MP 18) Z4 and Z6 beds (Fig. 1A).

Paratype-MCNA 10183, skull fragment, showing the right and left M1-M3 molar series; MCNA 11888, left P3-4; MCNA 11906, left P1-2; MCNA 13372, left p4; and MCNA 13373, right p1.

Referred Specimens-MCNA 11904, right P3-4; MCNA 11887, 11893, left P3-4; MCNA 13375, fragment of the left P3-4; MCNA 11905, fragment of the left P3-4; MCNA 11950, right P1-2 (incomplete lingually); MCNA 13374, fragment of the right upper premolar; MCNA 11951, fragment of the upper premolar; MCNA 11952, fragment of the lower premolar.

Distribution-Only known in the type locality.

Diagnosis - Species of Iberolophus gen. nov., characterized by having in combination (1) four similar premolars, with two welldeveloped high and pointed cusps in all of them and without a significant talon/talonid length gradient between them; (2) a very lophodont and heterodont molar series, without discrete paraconule and metaconule, and with a large length increase from $\mathrm{M} 2 / \mathrm{m} 2$ to $\mathrm{M} 3 / \mathrm{m} 3$; and (3) a long postcanine diastema.

Differential Diagnosis-Bigger species than that of Mazaterón, differing from it in having (1) a shorter premolar series; (2) premolars with two well-developed high and pointed cusps anteriorly and similar talon/talonid length; and (3) a larger length increase from $\mathrm{M} 2 / \mathrm{m} 2$ to $\mathrm{M} 3 / \mathrm{m} 3$.

\section{DESCRIPTION}

The mandible and the skull fragments were found in close proximity to each other. Despite the absence of all upper premolars in the maxilla, the correspondence in size and the morphology and wear pattern of the preserved molars suggest that these fragments belong to the same taxon; they could even belong to the same individual. The upper isolated premolars exhibit a size and morphology which is similar to that of the lower premolars preserved in the mandible, so they are also included within the same taxon.

\section{Mandible and Skull}

The mandible is crushed (Figs. 2, 3: 5, 6). The right hemimandible was found broken anteriorly, but stuck to the rest of the mandible by a calcite crust (Fig. 2: 6). The mandibular ramus is low, gradually increasing in height backwards. The mandibular symphysis appears to be quite narrow and long. There is a long postcanine diastema (Table 1). The ascending ramus is not preserved in any of the hemimandibles. The skull fragment is also crushed and broken (Figs. 2, 3:1). Its size seems small in relation to molar robustness, but it is difficult to provide any reliable measurements due to crushing. The incomplete occipital and parietal regions are the best preserved elements of the skull, which can be described as follows: the occipital crests and condyles are thick; the medial, left and big occipital crests, and the left condyle are visible. The eye socket is not preserved. The zygomatic arch is broken and crushed, but it seems to have been thin and extended backward. The temporal fossa may have been quite wide.

\section{Dentition}

The incisor alveoli and the right canine root fragment preserved in the mandible suggest that the incisors are small and the canines are not thick (Figs. 2, 3: 5). There are four premolars, which have similar size and morphology. Although the first is incomplete, an isolated p1 is available for study (Figs. 1, 2: 7). Premolars are considerably smaller than the molars and exhibit unusual non-lophoid morphology, which has not been reported in any other equoid. In contrast, the morphology of the molars is typical of the Paleogene equoids, showing well-developed crests (lophs and lophids) (Figs. 2, 3: 1). The complete (with P1/p1) and very long premolar series is combined with a very lophodont and heterodont molar series, and a long postcanine diastema. The enamel of the teeth is quite thick.

It is not easy to differentiate the P1-P4 isolated teeth, although the slightly smaller and wider than longer teeth seem be anterior premolars (Table 1). They have a semicircular outline in the occlusal view and a sharp cingulum encircles all of them (Figs. 2, 3: 2-4). It is difficult to describe the occlusal surface of the anterior premolars in detail, due to their substantial wear. However, all premolars seem to have two well-developed high and pointed cusps anteriorly, and a low and wide talon posteriorly, the latter being characterized by having a bumpy enamel surface texture. Two very short and narrow crests leave from the internal cusp toward the labial side; the posterior crest terminates in the external cusp, whereas the anterior crest descends towards the crown base on the labial side. The M1-M3 series is lophodont, without discrete paraconule and metaconule, and heterodont. M1 is smaller and less hypsodont than M2-M3. M1 and M2 are wider than longer, with a rectangular outline in the occlusal view, whereas M3 exhibits a narrower posterior lobe than the anterior one, showing a trapezoidal outline (Figs. 2, 3: 1). Severe M1 wearing prevents a detailed description of its crests in the occlusal view. In the M2-M3 the protoloph and metaloph are obliquely oriented to the ectoloph. The metaloph is joined with the ectoloph at the level of the mesostyle. Although the styles (parastyle, mesostyle and metastyle) are thick, exhibiting prominent ribs on the labial side, they do not strongly protrude labially in the occlusal view, and do not show a strong "W"-shaped ectoloph. The lingual cingulum is thick, but it is only present on the base of the protocone. The labial cingulum is almost continuous.

The p1-p4 series is very long (Table 1). All premolars have high and pointed internal and external cusps, which are connected by a short and narrow transverse crest in the worn teeth, and a low and long backward extending talonid, with a bumpy enamel surface texture (Figs. 2, 3:5-8). Their cingulum is sharp and continuous. The talonid length decreases slightly from $\mathrm{p} 1$ to $\mathrm{p} 4$, with the anterior premolars appearing slightly longer than the posterior ones (Table 1). The molar series is lophodont and heterodont, with $\mathrm{m} 3$ appearing to be significantly larger than $\mathrm{m} 2$ (Table 1). There is no twinned metaconid in $\mathrm{m} 1-\mathrm{m} 3$. The $\mathrm{m} 1$ and $\mathrm{m} 2$ are too worn to evaluate the development of the hypoconulid. The hypoconulid size of $\mathrm{m} 3$ is similar to those of the anterior and posterior lobes (Figs. 2, 3: 5, 6). The labial cingulum only appears on the labial grooves, between the protoconid and hy-

FIGURE 2. Iberolophus arabensis gen. et sp. nov. (Equoidea, Perissodactyla) from the Late Eocene of Zambrana (Araba, Basque Country). 1, skull fragment (MCNA 10183, paratype), showing the right and left M1-M3 series; 2, left P1-2 (MCNA 11906, paratype); 3-4, left P3-4 (MCNA 11887; 11888, paratype); 5-6, mandible (MCNA 11953, holotype), showing incisors and canine alveoli, a fragment of the right canine root, and the left C-m3 (p1 and $\mathrm{m} 1$ incomplete) and right p3-m3 series; 7, right p1 (MCNA 13373, paratype); and 8, left p4 (MCNA 13372, paratype). A, occlusal; B, labial; and $\mathbf{C}$, lingual views. Scale bars equal 2 and $3 \mathrm{~cm}$. Fossils are coated with ammonium chloride. 


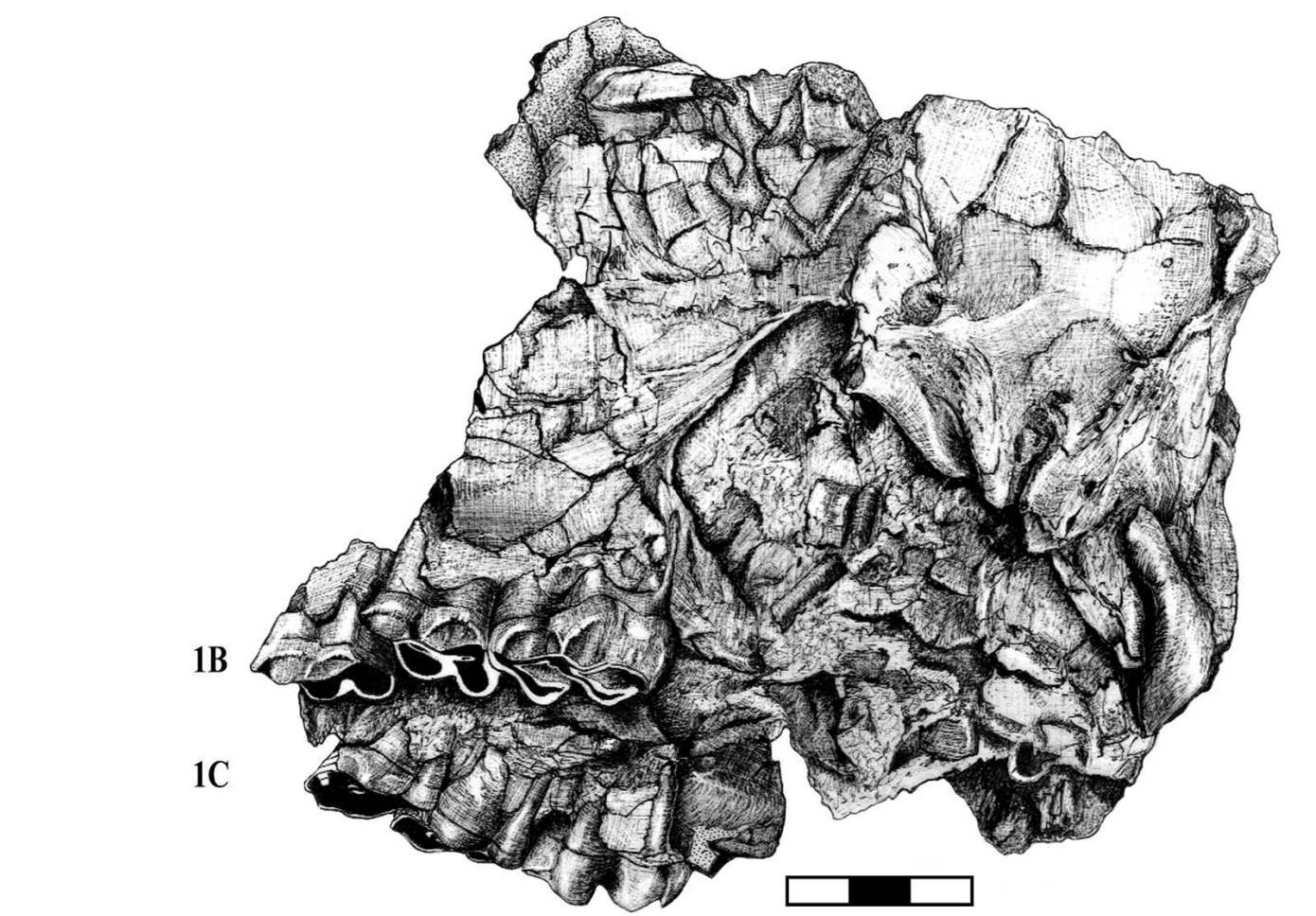

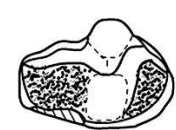

$8 \mathrm{~A}$

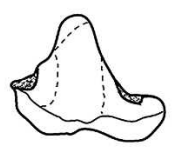

$8 \mathrm{~B}$

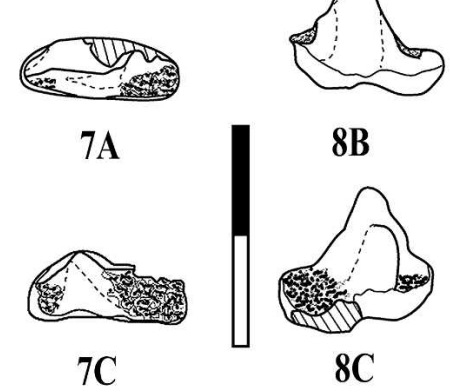

$4 \mathrm{~A}$
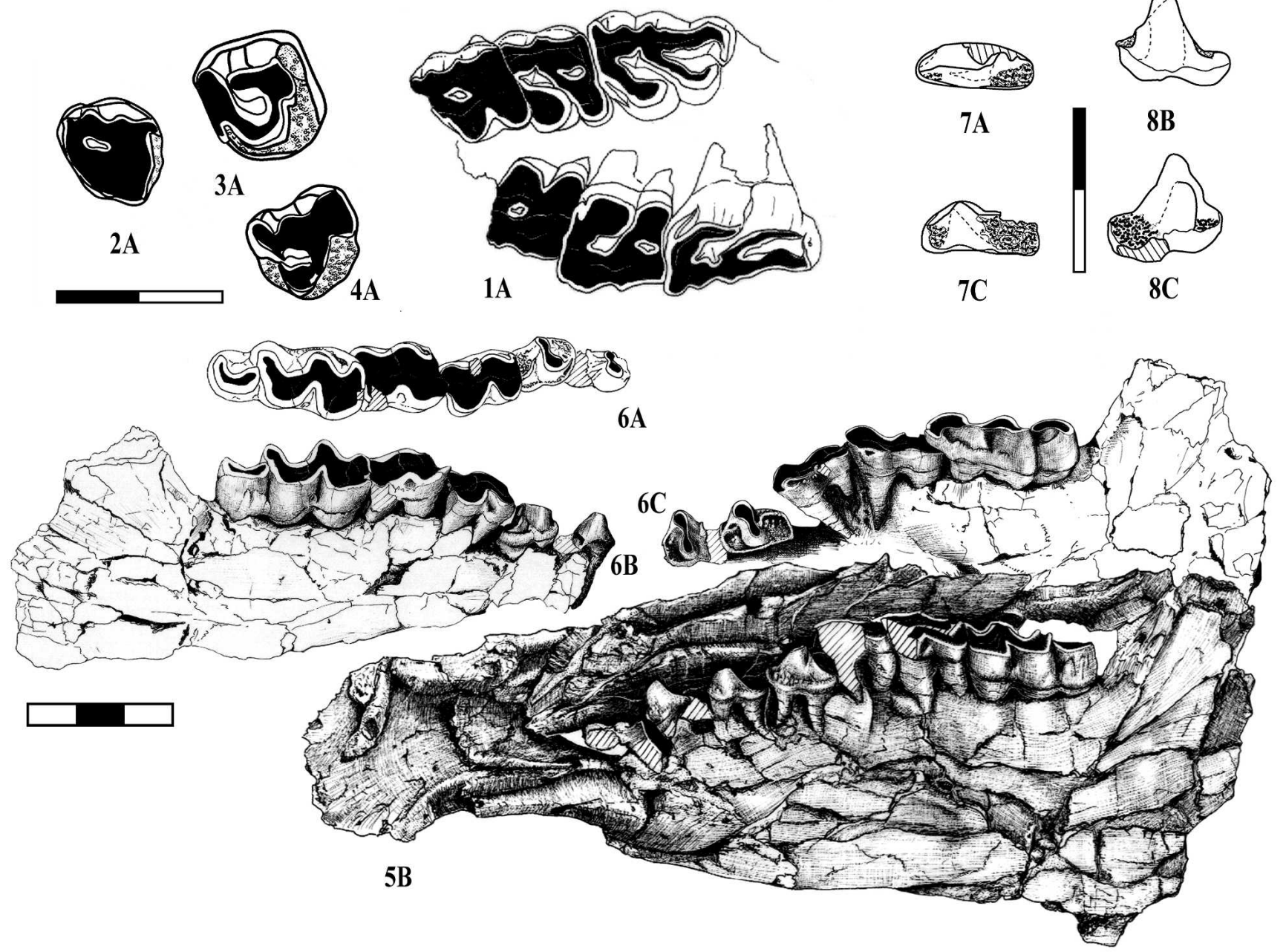

FIGURE 3. Drawings of the cranial and dental elements of Iberolophus arabensis gen. et sp. nov. (Equoidea, Perissodactyla) from the Late Eocene of Zambrana (Araba, Basque Country). Scale bars equal 2 and $3 \mathrm{~cm}$. See abbreviations in legend to Figure 2 . Drawings 1 , 5 , and 6 by H. Astibia. 
TABLE 1. Dental measurements (in $\mathrm{mm}$ ) of Iberolophus arabensis gen. et sp. nov. (Equoidea, Perissodactyla) from the Late Eocene (Headonian) of Zambrana (Araba, Basque Country).

\begin{tabular}{|c|c|c|c|c|c|c|}
\hline & MCNA & $\mathrm{L}$ & W & $\mathrm{L} / \mathrm{W}$ & D & d \\
\hline \multirow[t]{2}{*}{ P1-2 } & 11906 & 12.1 & 14.2 & 0.85 & & \\
\hline & 11950 & 12.1 & 14.4 & 0.84 & & \\
\hline \multirow[t]{5}{*}{ P3-4 } & 11904 & 12.1 & 13 & 0.93 & & \\
\hline & 11888 & 12 & 13.7 & 0.88 & & \\
\hline & 11893 & 12.7 & 13.6 & 0.93 & & \\
\hline & 11887 & 13.6 & 14 & 0.97 & & \\
\hline & 11905 & са. 14.8 & - & & & \\
\hline \multirow[t]{2}{*}{ M1 } & 10183(l) & ca. 16.2 & - & & 21.5 & 17.1 \\
\hline & 10183(r) & са. 15.5 & 17.7 & ca. 0.88 & 20.3 & 17.5 \\
\hline \multirow[t]{2}{*}{ M2 } & 10183(l) & ca. 18 & - & & ca. 22.4 & ca. 18.4 \\
\hline & 10183(r) & 18.7 & 20 & 0.94 & 22.7 & 19.4 \\
\hline \multirow[t]{3}{*}{ M3 } & 10183(l) & 27.9 & - & & 23.9 & 20.1 \\
\hline & 10183(r) & 27.9 & 20.5 & 1.36 & 22.9 & 20.9 \\
\hline & MCNA & $\mathrm{L}$ & W & Wa & $\mathrm{Wp}$ & Wpp \\
\hline \multirow[t]{2}{*}{ p1 } & 11953(1) & (14) & - & & & \\
\hline & 13373 & 14.7 & 5.4 & & & \\
\hline p2 & 11953(1) & (13.8) & - & & & \\
\hline \multirow[t]{2}{*}{ p3 } & 11953(1) & (13.6) & - & & & \\
\hline & 11953(r) & 14 & 8.8 & & & \\
\hline \multirow[t]{3}{*}{ p4 } & 11953(1) & (13.6) & - & & & \\
\hline & 11953(r) & 14.1 & 9.2 & & & \\
\hline & 13372 & 14.3 & 9.6 & & & \\
\hline \multirow[t]{2}{*}{$\mathrm{m} 1$} & 11953(l) & (15.6) & - & & & \\
\hline & 11953(r) & 16 & & 10.2 & 10 & \\
\hline \multirow[t]{2}{*}{$\mathrm{m} 2$} & 11953(l) & (16.4) & - & & & \\
\hline & 11953(r) & ca. 16.5 & & 12.5 & ca. 12.4 & \\
\hline \multirow[t]{2}{*}{$\mathrm{m} 3$} & 11953(1) & (28.3) & - & & & \\
\hline & 11953(r) & 28.4 & & 13.5 & 12.3 & 9.3 \\
\hline MCNA & LC-p1 & $\mathrm{ID}^{\prime}$ & Lp1-p4 & Lm1-m3 & Lp1-m3 & $\mathrm{PMI}^{\prime}$ \\
\hline 11953(l) & $(23.5)$ & ca. 20.38 & $(55)$ & $(60.3)$ & (115.3) & ca. 91.21 \\
\hline
\end{tabular}

Abbreviations: L, length; $\mathbf{W}$, width; $\mathbf{D}$, maximum diagonal from the parastyle to the hypocone; $\mathbf{d}$, perpendicular diagonal to D; Wa, width of the anterior lobe; Wp, width of the posterior lobe; Wpp, width of the hypoconulid; ID', diastema index including the p1 (LC-p4/Lp1-m3 $\times$ 100); and PMI' ${ }^{\prime}$ molarization index including the p1 (Lp1-p4/Lm1-m3 $\times$ $100)$.

poconid, whereas the lingual cingulum is more continuous, mainly in $\mathrm{m} 3$.

\section{IBEROLOPHUS JIMENEZI, sp. nov.} (Fig. 4)

Holotype-US 11800, right hemimandible, exhibiting p1 and $\mathrm{m} 1$ alveoli, and the $\mathrm{p} 2-\mathrm{p} 4$ and $\mathrm{m} 2-\mathrm{m} 3$ series.

Etymology-After Dr. Emiliano Jiménez, professor of Geology of the University of Salamanca (Castilla y León), for his important contribution to the study of reptilian fossils of the Duero Basin, and for his untiring efforts to manage an impressive vertebrate fossil collection of the Duero Basin in the "Sala de las Tortugas" of the University of Salamanca.

Type Locality and Horizon-Mazaterón (Soria), Iberian Peninsula; Almazán Basin, Robiacian (MP 15-16) beds (Fig. 1B).

Distribution-Only known in the type locality.

Diagnosis-Species of Iberolophus gen. nov., characterized by having an extremely long premolar series, clearly longer than the molar series, together with premolars having only one welldeveloped high and pointed cusp and with longer talonids in the anterior teeth than in the posterior ones.

Differential Diagnosis - Smaller species than that of Zambrana, differing from it in having (1) a longer premolar series; (2) premolars with only one well-developed high and pointed cusp; (3) a larger talonid length gradient in p1-p4; and (4) with a smaller length increase from $\mathrm{m} 2$ to $\mathrm{m} 3$.

\section{DESCRIPTION}

\section{Mandible}

The right hemimandible found in Mazaterón is anteriorly broken, where the $\mathrm{p} 1$ and $\mathrm{m} 1$ alveoli and the $\mathrm{p} 2-\mathrm{p} 4$ and $\mathrm{m} 2-\mathrm{m} 3$ series are preserved (Fig. 4). The mandibular ramus is quite thin and the ascending ramus is quite short; it does not seem to extend backwards further than the level of the mandibular condyle. The latter is thick. The angular and coronoid processes are not completely preserved.

\section{Dentition}

The premolar series is complete (with $\mathrm{p} 1$ ) and considerably longer than the molar series (Table 2). Regarding the premolars, the internal cusp is absent or it is not well-developed, and the low talonid, which exhibits a bumpy enamel surface texture, is clearly longer in the anterior premolars than in the posterior ones (Table 2). The molars are lophodont with narrow and closed "V"-shaped crests (Fig. 4B). There is no twinned metaconid in the $\mathrm{m} 1-\mathrm{m} 3$ series. A small hypoconulid is visible in $\mathrm{m} 2$, whereas in $\mathrm{m} 3$ it is as high as the anterior and posterior lobes (Fig. 4A, C). A sharp cingulum encircles all premolars, whereas it is not continuous in the molars. There is no cement in the teeth.

\section{DISCUSSION}

The unusual dental pattern that is exhibited by the new taxa from Zambrana and Mazaterón has not been reported to date in any other equoid. Non-lophoid premolars, which exhibit one (in the earlier members) or two (in the later members) welldeveloped high and pointed cusp(s) anteriorly, and a low and backward extending talon/talonid posteriorly, with a bumpy surface texture, are present together with typical Paleogene equoid molars in the same cheek tooth row. With respect to the molar series, the new equoid Iberolophus gen. nov., differs from $\mathrm{Pal}$ aeotherium and relatives in lacking (1) lower molars with thinner enamel on the lingual side than on the labial side; (2) upper molars with a smaller hypocone than protocone; (3) higher external cusps (paracone and metacone) than the internal ones (hypocone and protocone); (4) a short and low protoloph and metaloph; and (5) a strong "W"-shaped ectoloph. The new taxa are bigger than those of Pachynolophinae Pavlow, 1888 and they differ from Pachynolophus and relatives in having a welldeveloped mesostyle in the upper molars, and in lacking a twinned metaconid in the lower molars. On the basis of the molar series features, the new specimens have been assigned to Plagiolophinae and they are here referred to as a new genus, i.e., Iberolophus arabensis sp. nov. (type species) and Iberolophus jimenezi $i \mathrm{sp}$. nov. Differences in the molar series are visible between Iberolophus gen. nov. and the rest of the plagiolophines (see differential diagnosis of the new genus).

Within plagiolophines, a number of teeth and skull features are shared in common between Iberolophus gen. nov., Metaplagiolophus and Leptolophus. In Metaplagiolophus and Iberolophus gen. nov., the upper molars are robust in comparison to the skull size, and thick occipital condyles and crests are visible in the occipital region. In the three genera, the upper molars are characterized by having a flat ectoloph, which is not strongly "W"shaped in the occlusal view, in comparison to that of the other plagiolophines (mainly Plagiolophus), and the lower molars do not have a twinned metaconid. However, there are differences in the molar and premolar series between them. With respect to the length of the premolar series, it is much shorter in Leptolophus than in Iberolophus gen. nov. In the mandible and skull fragments assigned to Metaplagiolophus, only four incomplete premolar alveoli have been preserved (Checa, 1993:97, 100, figs. 2, 3 ). Consequently, the morphology of the premolar series is incompletely known, but the premolar series is shorter than in 


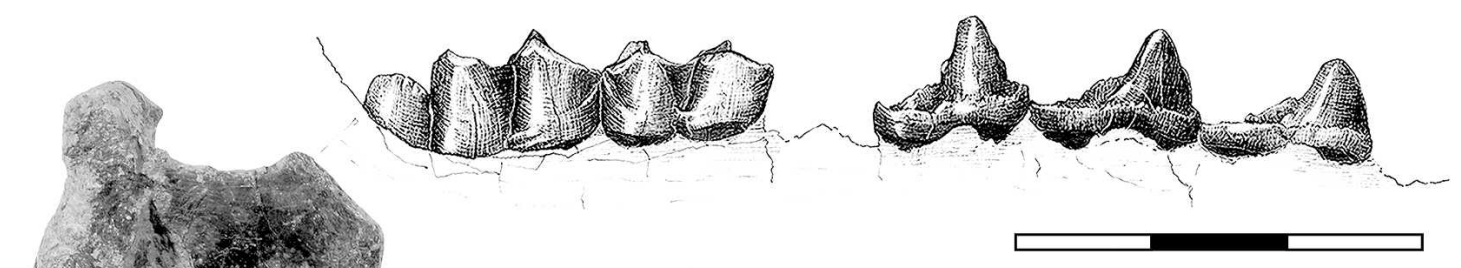

A
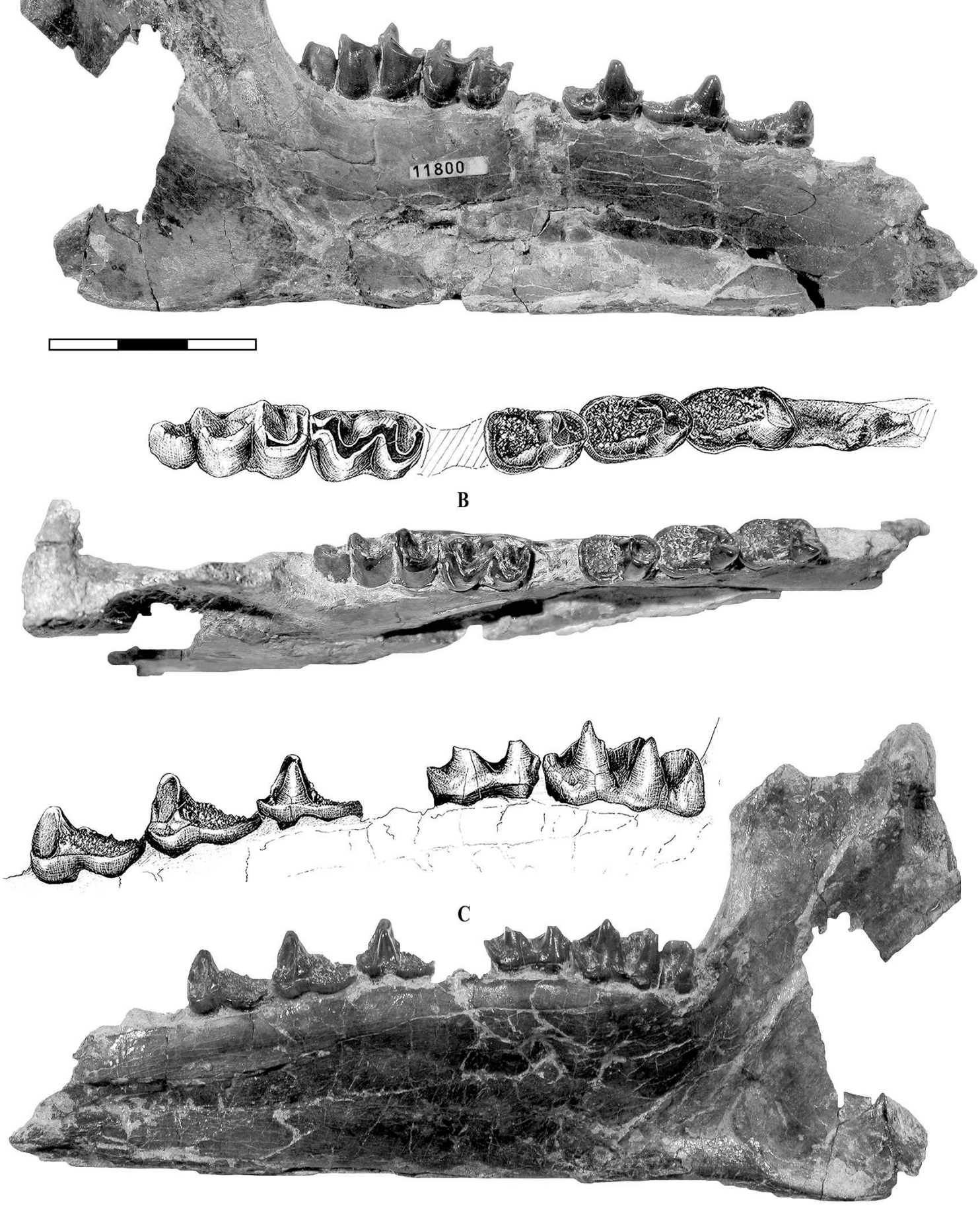

FIGURE 4. Iberolophus jimenezi gen. et sp. nov. (Equoidea, Perissodactyla) from the late Middle Eocene of Mazaterón (Soria, Castilla y León). Photos and drawings of the right hemimandible (US 11800, holotype) with the p1 and $\mathrm{m} 1$ alveoli, and the p2-p4 and $\mathrm{m} 2-\mathrm{m} 3 \mathrm{series}$. A, labial; B, occlusal; and $\mathbf{C}$, lingual views. Scale bar equals $3 \mathrm{~cm}$. Drawings by H. Astibia. 
TABLE 2. Dental measurements (in $\mathrm{mm}$ ) of Iberolophus jimenezi gen. et sp. nov. (Equoidea, Perissodactyla) from the late Middle Eocene of Mazaterón (Soria, Castilla y León).

\begin{tabular}{|c|c|c|c|c|c|}
\hline US11800 & $\mathrm{L}$ & W & Wa & $\mathrm{Wp}$ & Wpp \\
\hline $\mathrm{p} 1$ & (15.8) & & & & \\
\hline p2 & 13.3 & 8 & & & \\
\hline p3 & 13.4 & 8.3 & & & \\
\hline p4 & 12 & 7.5 & & & \\
\hline $\mathrm{m} 2$ & 13 & & 7.8 & 7.9 & \\
\hline \multirow[t]{2}{*}{$\mathrm{m} 3$} & ca. 19.2 & & 8.3 & 7.4 & ca. 5.7 \\
\hline & Lp1-p4 & $\mathrm{Lm} 1-\mathrm{m} 3$ & Lp1-m3 & $\mathrm{PMI}^{\prime}$ & \\
\hline US11800 & ca. 51.8 & ca. 38.4 & ca. 89.3 & ca. 134.89 & \\
\hline
\end{tabular}

Abbreviations: L, length; W, width; $\mathbf{D}$, maximum diagonal from the parastyle to the hypocone; d, perpendicular diagonal to D; Wa, width of the anterior lobe; $\mathbf{W p}$, width of the posterior lobe; Wpp, width of the hypoconulid; and $\mathbf{P M I} \mathbf{I}^{\prime}$, molarization index including the p1 (Lp1-p4/ Lm1-m3 × 100).

Iberolophus (Table 3). For the differences in the molar series see the differential diagnosis of the new genus.

Iberolophus arabensis sp. nov. from Zambrana is bigger than Iberolophus jimenezi sp. nov. from Mazaterón and exhibits a shorter premolar series (Table 3), in which all premolars exhibit two well-developed high and pointed cusps anteriorly, instead of only one, and a smaller talonid length gradient is observed in the p1-p4 series. In the molar series, a larger length increase from $\mathrm{m} 2$ to $\mathrm{m} 3$ is present in $I$. arabensis sp. nov. (Table 3 ). The dentition features of $I$. arabensis sp. nov. can be considered more derived than those of $I$. jimenezi sp. nov. This interpretation is consistent with the younger age of Zambrana (Headonian, MP 18) relative to Mazaterón (Robiacian, MP 15-16). It is clear that both species are related to each other. Iberolophus jimenezi $\mathrm{sp}$. nov. may be a possible ancestor of the species from Zambrana. The presence of four non-molariform premolars and a long premolar series are considered plesiomorphic features within Plagiolophinae, whereas the tendency to shorten the premolar series, the accentuation of lophodonty, and the presence of a very heterodont molar series and a long postcanine diastema are more derived features. Heterodonty in the molar series is associated with a shorter premolar series, whereas lophodonty is usually accompanied by the presence of cement in the crown (e.g., in Leptolophus and in the Late Eocene species of Plagiolophus). However, these combinations are not observed in the new taxa from Zambrana and Mazaterón. The long premolar series exhibited by I. arabensis sp. nov., is unusual for the Late Eocene plagiolophines. In contrast, other dentition features, such as lophodonty, hypsodonty and heterodonty of the molar series, and the length of the postcanine diastema, are similar to those of taxa from the late Middle Eocene and Late Eocene. The postcanine diastema index and the $\mathrm{m} 3 / \mathrm{m} 2$ ratio length are similar to those of Leptolophus and to the Late Eocene and Oligocene species of Plagiolophus. In contrast, the molarization index (the ratio length of the premolar and molar series) is much higher (Table 3). The new plagiolophine Iberolophus gen. nov. is characterized by having a combination of plesiomorphic (complete, with P1/p1, and very long non-molariform premolar series) and specialized tooth features (lophodont and heterodont molar series and a long postcanine diastema) which is clearly distinct to that of its nearest European relatives.

TABLE 3. Comparison of the postcanine diastema index $(\mathbf{I D}=\mathrm{LC}-\mathrm{p} 2 / \mathrm{Lp} 2-\mathrm{m} 3 \times 100)$, the molarization index $(\mathbf{P M I}=\mathrm{Lp} 2-\mathrm{p} 4 / \mathrm{Lm} 1-\mathrm{m} 3 \times 100)$ and the $\mathrm{m} 3 / \mathrm{m} 2$ length $(\mathrm{Lm} 3 / \mathrm{Lm} 2)$ in several Eocene and Oligocene plagiolophines of Europe.

\begin{tabular}{|c|c|c|c|c|c|}
\hline Taxa & Site and MP Level & Source of data & ID (\%) & PMI (\%) & $\mathrm{Lm} 3 / \mathrm{Lm} 2$ \\
\hline Plagiolophus javali & RAY (MP25) & $\begin{array}{l}\text { Brunet \& Jehenne (1989) } \\
\text { Remy (2004) Ou-16516 }\end{array}$ & 42.9 & 49 & 1.22 \\
\hline Plagiolophus huerzeleri & MR (MP 23) & Remy (2004) & 52.5 & 50 & - \\
\hline Plagiolophus ministri & VIL (MP 22) & Remy (2004) & 52.9 & 51.4 & 1.52 \\
\hline & RO (MP 21) & Remy (2004) & 47.3 & 50.9 & 1.41 \\
\hline Plagiolophus ringeadei & RU (MP 21) & Remy (2004). FPO RU-3 & 48.9 & 49.3 & 1.64 \\
\hline $\begin{array}{l}\text { Plagiolophus fraasi } \\
\text { Plagiolophus minor }\end{array}$ & FH (MP 20) & Remy (2004) & - & 54.5 & $1.42 *$ \\
\hline Plagiolophus major & SCE (MP 20) & Brunet \& Jehenne (1989) & 27.98 & 48.53 & 1.72 \\
\hline Plagiolophus oweni & FA (MP 18) & Remy (2004) & 32.2 & 53.31 & 1.46 \\
\hline \multirow{5}{*}{ Plagiolophus annectens } & LDB (MP 18) & NHM-M.28229(1) & & ca. 53.1 & - \\
\hline & & NHM-M.28229(r) & & ca. 52.52 & ca. 1.46 \\
\hline & HC (MP 17) & NHM-B.M.29730(1) & ca. 28.91 & ca. 55.77 & 1.33 \\
\hline & & NHM-B.M.29730(r) & ca. 33.8 & ca. 54.52 & 1.39 \\
\hline & EUZ (MP 17) & NHM-M.9842(1) & & ca. 55.47 & 1.57 \\
\hline Iberolophus arabensis & ZAM (MP 18) & This paper & ca. 43.78 ca. $20.38^{*}$ & ca. 68 ca. $91.21^{*}$ & 1.72 \\
\hline Iberolophus jimenezi & MAZ (MP 15-16) & This paper & & ca. 93.57 ca. $134.89^{*}$ & 1.48 \\
\hline Leptolophus nouleti & CAS, ROB (MP 16) & Remy (1998) & & 53.68 & 1.56 \\
\hline Leptolophus stehlini & CAS, ROB (MP 16) & Remy (1998) & & & 1.73 \\
\hline Plagiolophus mamertensis & ROB (MP 16) & Remy (2004) & - & 46.7 & - \\
\hline Plagiolophus mazateronensis & MAZ (MP 15-16) & Cuesta (1994a) & & $56.3654 .87 *$ & 1.55 \\
\hline Metaplagiolophus atoae & SJF (MP 15) & Checa (1993) & 23.3 & 49.65 & 1.53 \\
\hline Plagiolophus cartieri & EG (MP 14) & Remy (2004) & - & 57.7 & 1.49 \\
\hline Plagiolophus casasecaensis & CASC (MP 13-14) & Cuesta (1994a) & & $66.1681 .17 *$ & 1.29 \\
\hline
\end{tabular}

The average measurements are taken from Remy (2004).

*ID' and IPM' measurements that include 1 .

Abbreviations: ID, diastema index (LC-p2/Lp2-m3 × 100); L, length; PMI, molarization index (Lp2/p4/Lm1-m3 × 100). See site abbreviations in the Introduction. 


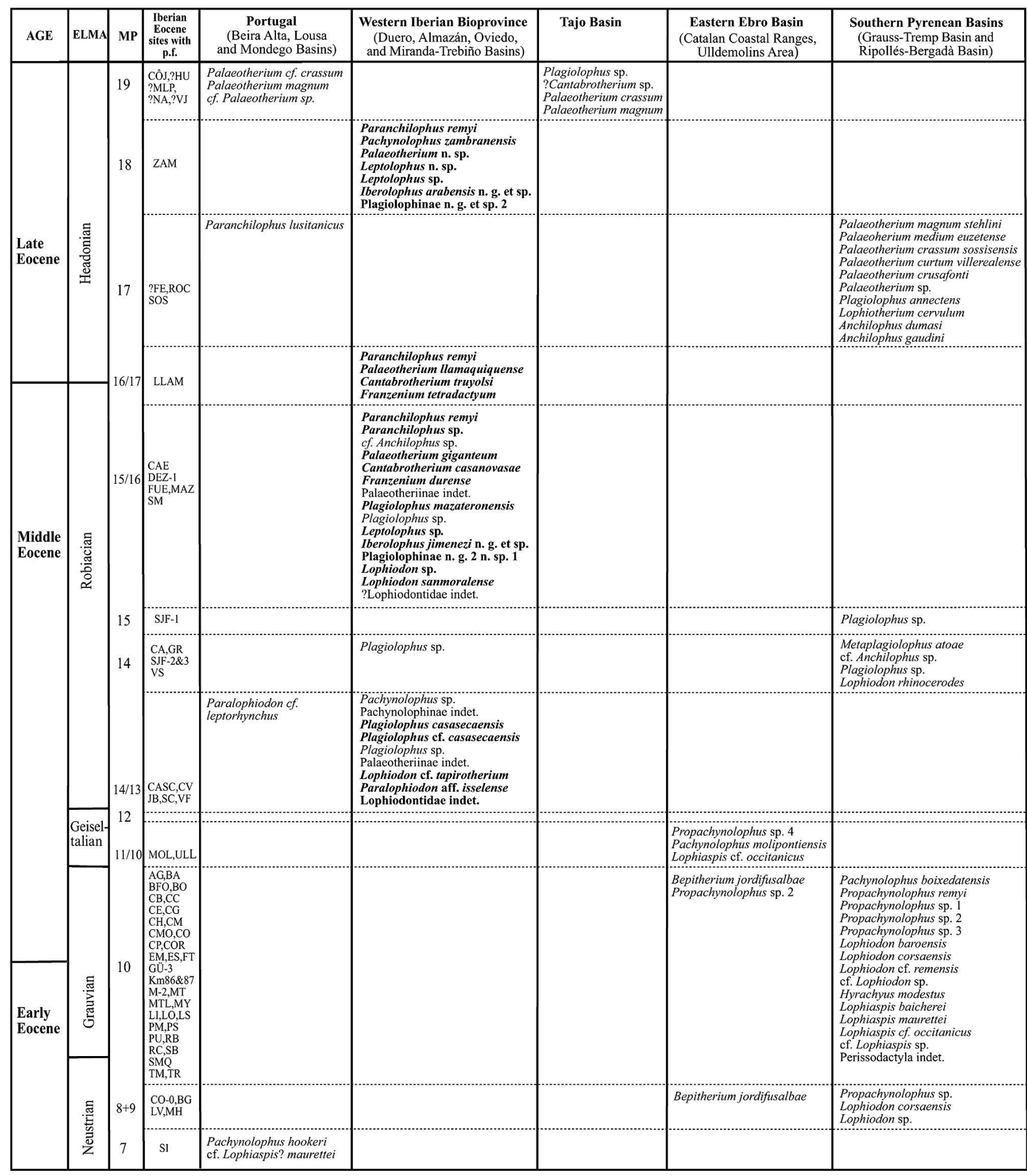

FIGURE 5. Iberian Eocene sites with perissodactyl fossils and chronology. Data source: a) Portugal (e.g., Antunes, 1986, 1992, 1995, Estravis, 2000, and Hooker, 1998: p. 433 for the reidentification of Hyracotherium cf. vulpiceps as Pachynolophus hookeri); b) Western Iberian Bioprovince (e.g., Casanovas \& Santafé, 1987, 1989, 1991; Cuesta, 1991, 1993, 1994a, 1994b, 1994c, 1996, 1999, 2003; Astibia et al., 2000; Badiola et al., 2002, 2005, in press., Badiola, 2004, and Cuesta et al. 2004); Tajo Basin (e.g., this paper, Crusafont et al., 1960, and Iriarte et al., 2006); d) Eastern Ebro Basin (e.g., Checa, 1995, 1997; Checa and Colombo, 2004); and e) Southern Pyrenean Basins (e.g., Casanovas, 1975; Casanovas et al., 1998; Checa and Casanovas, 1989-1990; and Checa, 1993, 1995, 1997). Abbreviations: p.f., perissodactyl fossils, ELMA, Eocene European Land Mammal Ages; MP, mammal Paleogene reference level; see the rest of abbreviations in the Introduction section (modified from Badiola et al., in press). 


\section{ENDEMIC PERISSODACTYL FAUNA IN THE IBERIAN PENINSULA}

In Europe, several bioprovinces are recognized to have existed during the Late Eocene on the basis of regional differences between rodent, primate, artiodactyl and perissodactyl faunas (e.g., Franzen, 1968; Hartenberger, 1973; Schmidt-Kittler and VianeyLiaud, 1975; Sudre, 1978; Vianey-Liaud, 1991; Hooker, 1992). However, this faunal differentiation is particularly pronounced between western Iberia and the rest of Europe. In the Iberian Peninsula, Middle and Late Eocene mammalian faunas (mainly perissodactyls, rodents and primates) of the western and central Iberian basins (Duero, Almazán, Oviedo and Miranda-Trebiño Basins) were clearly different to those of the Southern Pyrenean Basins (Fig. 1) and the rest of Europe (e.g., Casanovas and Santafé, 1987, 1989, 1991; Casanovas and Moyà-Solà, 1992; Cuesta, 1991, 1999, 2003; Peláez-Campomanes, 1993). On the basis of this faunal differentiation, the existence of a Western Iberian Bioprovince has been hypothesized (Cuesta, 1991; Badiola, 2004; Badiola et al. in press). In contrast, the Middle and Late Eocene mammalian faunas of the Southern Pyrenees were similar to those of the southern part of the Central European Islandpresent southern France and Switzerland-where the typical western Iberian endemic taxa were absent (e.g., Casanovas, 1975; Checa, 1997; Casanovas et al., 1998; Cuesta et al., 2006).

The best-known localities in the Western Iberian Bioprovince are the late Middle Eocene beds at Mazaterón (Almazán Basin) and the Late Eocene beds at Zambrana (Miranda-Trebiño Basin), which have yielded twenty and twenty-two mammalian taxa, of which nine and seven are perissodactyls, respectively (e.g., Cuesta, 1999, 2003; Astibia et al. 2000; Badiola, 2004; Badiola et al., 2002, 2005). The mammal fossil assemblages of these localities have increased the resolution of Iberian late Middle Eocene and Late Eocene mammalian biostratigraphy, and they have been essential for testing the hypothesis of faunal differentiation in this bioprovince. Moreover, the endemism of the perissodactyl faunas can be shown to exist at least from the late Middle Eocene to the Late Eocene in the central and western Iberian basins, because the perissodactyl fossils from the middle Headonian beds at Zambrana are related to endemic taxa from late Robiacian beds of the Duero, Almazán and Oviedo Basins (Badiola, 2004). The paleobiological study of the mammal fossil assemblage from Zambrana has also provided significant data on the Iberian and wider European mammalian paleoecology and paleobiogeography in southwestern Europe at this time (Badiola et al., in press). With respect to perissodactyls, to date, five genera and sixteen species of equoids and five taxa of lophiodonts, which are unknown elsewhere in Europe, have been identified to date in the Western Iberian Bioprovince (taxa indicated in black in Fig. 5). In the context of Iberian biochronology, primate and rodent fossils are less well known than perissodactyls. However, various taxa have been described from the Middle and Late Eocene beds of the Duero and Almazán Basins and MirandaTrebiño Basin, respectively, which are unknown elsewhere in Europe. Others are close to those of southwestern Europe, but because of their more derived dental features (mainly larger size and more hypsodont dentition), they are not included within the same species (see taxa in Badiola et al., in press).

A period of isolation of the Iberian Peninsula from the Central European island until the late Lutetian (Decourt et al. 1986; Meulekamp et al. 2000), albeit with intermittent faunal exchange with the rest of Europe and with the other continents (probably Asia and Africa), could have caused the endemism of the Eocene mammal faunas of the Iberian Peninsula. Moreover, the special paleoecological conditions of western Iberia, with more open environments and probably more arid ecological conditions, which seem to have existed at least since the late Middle Eocene (Badiola and Cuesta, 2007b), could have been the main causes of the faunal differentiation of the Western Iberian Bioprovince (Badiola et al., in press). The paleogeographic and paleoecological barriers, however, could not have been influenced in the same way for all mammalian fauna, because perissodactyl fossils from the Late Eocene beds at Zambrana are clearly related to endemic forms from the late Middle Eocene of the Duero, Almazán and Oviedo Basins, whereas typical Central European artiodactyl taxa are present alongside them: Anoplotherium laurillardi Pomel, 1851, Anoplotherium sp., Oxacroniinae indet., Xiphodon gracilis Cuvier, 1822, Haplomeryx sp., and Dichobune leporina Cuvier, 1822 (Badiola, 2004). A new Middle Eocene anoplotheriine artiodactyl has recently been found at the Mazaterón site in the Western Iberian Bioprovince (Cuesta and Badiola, 2007), but more Middle Eocene artiodactyl fossils are required to test the hypothesis of an artiodactyl faunal differentiation between the two areas during the late Middle Eocene.

Detailed paleobiological studied of the mammal fossil assemblages of the Western Iberian Bioprovince, including cladistic analysis, together with additional field work in the Eocene beds in the Iberian Peninsula, will be essential for further evaluation of faunal differentiation and endemism in the Western Iberian Bioprovince.

\section{ACKNOWLEDGMENTS}

We would like to thank J. C. Corral (MCNA) for preparing the fossils from Zambrana, I. Gaztambide for taking the photographs, and Dr. H. Astibia for drawings of the specimens. We are also grateful to Drs. J. Alonso (MCNA), E. Jiménez (US), A. Galobart and L. Casanovas (IPS), M. Brunet (UPO), P. Tassy (MNHN), J. A. Remy (USTL), B. Engesser (NMB), J. J. Hooker (NHM), A. Prieur (UCBL) and Mr. M. Philippe (MNSL) for their help and access to specimens, to the editors (Drs. M. Wilson, R. Asher, and R. Reisz) and referees (one of them was Dr. J. A. Remy) of this paper for helpful comments on an earlier version, and everyone who took part in the field work. Financial support was provided by Arabako Foru Aldundia, The Ministerio de Educación y Ciencia (BOS2000-1369 and CGL2004-02338/ BTE) and by the Euskal Herriko Unibertsitatea/UPV (9/UPV 00121.310-15303/2003). The first author acknowledges support from the Ministerio de Educación y Ciencia (predoctoral grant and Juan de la Cierva research contract) and Eusko Jaurlaritza/ GV (postdoctoral grant).

\section{LITERATURE CITED}

Aguilar, J.-P., S. Legendre, and J. Michaux. 1997. Synthèses et tableaux de corrélations; pp. 769-805 in J.-P. Aguilar, S. Legendre and J. Michaux (eds.), Actes du Congrès BiochroM'97. Mémoires et Travaux de l'Institut de Montpellier (EPHE) 21, Montpellier, France.

Alonso-Gavilán, G., I. Armenteros, J. Carballeira, A. Corrochano, P. Huerta and J. M. Rodríguez. 2004. Cuenca del Duero; pp. 550-557 in J. A. Vera (ed.), Geología de España. Sociedad Geológica de España, Instituto Geológico y Minero de España, Madrid.

Antunes, M. T. 1986. Paralophiodon cf. leptorhynchum (Tapiroidea, Mammalia) à Vale Furado: contribution à la connaissance de l'Éocène au Portugal. Ciências da Terra (Universidade Nova de Lisboa) 8:87-98.

Antunes, M. T. 1992. Contributions to the Eocene Palaeontology and Stratigraphy of Beira Alta, Portugal II. New late Eocene mammalian remnants from Côja, Portugal and the presence of Palaeotherium magnum Cuvier. Ciências da Terra (Universidade Nova de Lisboa) 11:83-89.

Antunes, M. T. 1995. On the Eocene Equid (Mammalia) from Feligueira Grande, Portugal, Paranchilophus lusitanicus (Ginsburg, 1965). Taxonomic status, Stratigraphic and Paleogeographical meaning. Comunicações, Instituto Geológico e Mineiro 81:57-72.

Antunes, M. T., M. L. Casanovas, M. A. Cuesta, Ll. Checa, J. V. Santafé, and J. Agustí. 1997. Eocene mammals from Iberian Peninsula; pp. 
337-352 in J. P. Aguilar, S. Legendre, and J. Michaux (eds.), Actes du Congrès BiochroM'97. Mémoires et Travaux de l'Institut de Montpellier (EPHE) 21, Montpellier, France.

Armenteros, I. 1994. Síntesis del Paleógeno del borde oriental de la Cuenca de Almazán (Soria): Geología del Yacimiento de Mazaterón. Stvdia Geologica Salmanticensia 29:145-156.

Astibia, H., A. Aranburu, X. Pereda-Suberbiola, X. Murelaga, C. Sesé, M. A. Cuesta, S. Moyà-Solà, J. I. Baceta, A. Badiola, and M. Köhler. 2000. Un nouveau gisement à vertébrés continentaux de l'Eocène supérieur de Zambrana (Bassin de Miranda-Treviño, Álava, Pays Basque). Geobios 32:233-248.

Badiola, A. 2004. Estudio paleontológico del yacimiento superior de Zambrana (Álava, Región Vasco-Cantábrica). Tafonomía, Paleobiología de Mamíferos e implicaciones Biocronológicos. Ph.D. dissertation (unpublished), Euskal Herriko Unibertsitatea/Universidad del País Vasco, Leioa, Basque Country, Spain, 417 pp.

Badiola, A., and M. A. Cuesta. 2007a. Los marsupiales del yacimiento del Eoceno Superior de Zambrana (Álava, Región VascoCantábrica). Estudios Geológicos 62:349-358.

Badiola, A., and M. A. Cuesta. 2007. Aproximación al estudio paleoambiental de la Península Ibérica en el Eoceno Medio y Superior a través del análisis paleoecológico de las faunas de mamíferos. XXIII Jornadas de la Sociedad Española de Paleontología, Caravaca de la Cruz, Spain, 4-6 October, 2007, pp. 17-18.

Badiola, A., H. Astibia, X. Pereda-Suberbiola, and X. Murelaga. 2002. First record of the genus Leptolophus Remy, 1965 (Mammalia, Perissodactyla) in the Late Eocene (Priabonian) of Europe. Geodiversitas 24:841-848.

Badiola, A., X. Pereda-Suberbiola, and M. A. Cuesta. 2005. Una nueva especie de Pachynolophus (Mammalia, Perissodactyla) de Zambrana (Álava, Región Vasco-Cantábrica). Análisis filogenético de Pachynolophus y primera cita en el Eoceno superior de la Península Ibérica. Geobios 38:1-16.

Badiola, A., Ll. Checa, M. A. Cuesta, R. Quer, J. I. Hooker, and H. Astibia. In press. The role of new Iberian finds in understanding European Eocene mammalian palaeobiogeography. Geologica Acta.

Bonaparte, C. L. 1850. 1. Conspectus Systematis Mastozoologiae. Editio altera reformata. Conspectus Systematum, Leiden.

Blondel, C. 2001. The Eocene-Oligocene ungulates from Western Europe and their environment. Palaeogeography, Palaeoclimatology, Palaeoecology 168:125-139.

Brunet, M. 1977. Les mammifères et le problème de la limite EocèneOligocène en Europe. Géobios (Mém. Spécial 1):11-27.

Brunet, M., and Y. Jehenne. 1989. Révision des genres Plagiolophus Pomel, 1847 et Paloplotherium Owen, 1848, Mammalia, Palaeotheriidae du Paléogène d'Europe; intérêt biochronologique. Annales de Paléontologie (Vertébrés) 75:23-52.

Casanovas, M. L. 1975. Estratigrafía y Paleontología del yacimiento Ludiense de Roc de Santa (Ârea del Noguera-Pallaresa). Ph.D. dissertation. Paleontología i Evolució 10:1-158.

Casanovas-Cladellas, M. L., and J V. Santafé-Llopis. 1987. Cantabrotherium truyolsi n. g., n. sp. (Palaeotheriidae, Perissodactyla) un exemple d'endémisme dans le Paléogène ibérique. Münchner Geowissenschaftliche Abhandlungen 10:243-252.

Casanovas-Cladellas, M. L., and J. V. Santafé-Llopis. 1989. Dos nuevos Paleotéridos (Perissodactyla, Mammalia) del yacimiento eocénico de Llamaquique (Oviedo). Trabajos de Geología, Universidad de Oviedo 18:337-352.

Casanovas, M. L., and J. V. Santafé. 1991-1992. Los Paleotéridos (Perissodactyla, Mammalia) de Llamaquique (Oviedo, España); pp. 101-108 in M. L. Casanovas, J.-V. Santafè, and J. Truyols (eds.), El yacimiento eocénico de Llamaquique (Oviedo, España) y su contenido paleontológico. Boletín de Ciencias de la Naturaleza, Instituto de Estudias Asturianos, v. 41.

Casanovas, M. L., and S. Moyà-Solà. 1992. La sucesión de faunas de mamíferos durante el Paleógeno europeo; pp. 187-234 in H. Astibia (Ed.), Paleontología de vertebrados. Faunas y Filogenia, Aplicación y Sociedad. Euskal Herriko Unibertsitatea/Universidad del País Vasco, Leioa, Basque Country, Spain.

Casanovas, M. L., Ll. Checa, and J. V. Santafé. 1998. Los perisodáctilos del yacimiento ludiense de Sossís (Cuenca Prepirenaica, Lleida, España); pp. 235-267 in N. López-Martínez, J. Civis, M. L. Casanovas-Cladellas, and R. Daams (eds.), Geología y Paleontología del
Eoceno de la Pobla de Segur (Lleida). Universitat de Lleida, Institut d'Estudis Ilerdencs, Lleida, Spain.

Checa, Ll. 1993. Avance descriptivo de un nuevo paleotérido (Mammalia, Perissodactyla) del yacimiento eoceno de Sant Jaume de Frontanyà 3 (Fm. Bellmunt, Prepirineo Catalán). Treballs del Museu de Geologia de Barcelona 3:91-116.

Checa, Ll. 1995. Los Perisodáctilos (Ungulata, Mammalia) del Eoceno Catalán. Ph.D. dissertation. University of Barcelona, Spain. Publications de la Universitat de Barcelona. Collecció de tesis doctorals microfitxadeş 2362.

Checa, Ll. 1997. Los perisodáctilos (Mammalia, Ungulata) del Eoceno catalán. Paleontologia i Evolució 30-31:149-234.

Checa, Ll., M. L. Casanovas. 1989-1990. El Eoceno Español: los yacimientos y sus faunas. Paleontologia i Evolució 23:17-39.

Checa, Ll., and F. Colombo. 2004. A new Early Palaeothere (Mammalia, Perissodactyla) from Northeastern Spain. Journal of Vertebrate Paleontology 24:507-512.

Crusafont-Pairó, M., B. Meléndez, and J. Truyols. 1960. El yacimiento de vertebrados de Huérmeces del Cerro (Guadalajara) y su significado cronoestratigráfico. Estudios Geológicos 16:243-254.

Cuesta, M. A. 1991. Perisodáctilos del Eoceno de la Cuenca del Duero. Ph.D. dissertation (unpublished), Universidad de Salamanca, Salamanca, Castilla y León, Spain, 322 pp.

Cuesta, M. A. 1993. Los Palaeotheriidae (Perissodactyla, Mammalia) del Eoceno de la Cuenca del Duero (Castilla y León, España). Estudios Geológicos 49:87-109.

Cuesta, M. A. 1994a. Los Plagiolophinae (Remy, 1976) nuevo rango (Perissodactyla, Mammalia) del Eoceno de la Cuenca del Duero (Castilla y León, España). Estudios Geológicos 50:253-279.

Cuesta, M. A. 1994b. Los Pachynolophinae (Equoidea, Perissodactyla, Mammalia) del Eoceno de la Cuenca del Duero (Castilla y León, España). Studia Geologica Salmanticensia 29:21-63.

Cuesta, M. A. 1994c. Los Lophiodontidae (Perissodactyla, Mammalia) del Eoceno de la Cuenca del Duero (Castilla y León, España). Studia Geologica Salmanticensia 29:23-65.

Cuesta, M. A. 1996. Primeros hallazgos de Lophiodontidae (Perissodactyla, Mammalia) en el yacimiento eocénico de Mazaterón (Cuenca del Duero, España): implicaciones bioestratigráficas. Studia Geologica Salmanticensia 32:39-48.

Cuesta, M. A. 1999. Las faunas de mamíferos del Eoceno de la Cuenca del Duero (Castilla y León, España). Síntesis Bioestratigráfica y Biogeográfica. Revista Española de Paleontología 14:203-216.

Cuesta, M. A. 2003. Mamíferos del Paleógeno de la Cuenca del Duero; pp. 197-236 in E. Jiménez Fuentes, and J. Civis Llovera (eds.), Los Vertebrados fósiles en la Historia de la vida. Excavación, estudio y Patrimonio. Universidad de Salamanca, Salamanca, Castilla y León.

Cuesta, M. A., and A. Jiménez. 1994. Síntesis del Paleógeno del borde oriental de la Cuenca de Almazán (Soria): vertebrados de Mazaterón. Stvdia Geologica Salmanticensia 29:157-170.

Cuesta, M. A., and A. Badiola. 2007. A new anoplotheriine artiodactyla from the Middle Eocene of the Iberian Peninsula. Journal of Vertebrate Paleontology 27(3, Supplement):63A.

Cuesta, M. A., E. Jiménez, and P. J. Pérez. 2004. Un caso de hipodoncia en un lofiodóntido (Perissodactyla, Mammalia) del Eoceno medio de la Cuenca del Duero (Castilla y León, España). Interpretación a luz de la agenesia dentaria humana. Revista Española de Paleontología 19:145-150.

Cuesta, M. A., Ll. Checa, and M. L. Casanovas. 2006. Los artiodáctilos del yacimiento ludiense de Sossís (Cuenca Prepirenaica, Lleida, España). Revista Española de Paleontología 21:123-144.

Cuvier, G. 1804-1805. Sur les espèces d'animaux dont proviennent les os fossiles répandus dans la pierre à plâtre des environs de Paris. Annales du Muséum National d'Histoire Naturelle, Paris 1804(3): 275-303,364-387,442-447.

Cuvier, G. 1822. Recherches sur les ossemens fossiles de quadrupèdes où l'on rétablit les caractères de plusieurs espèces d'animaux que les révolutions du globe paroissent avoir détruites. Nouvelle éd., Paris, vol. 2: 648 pp; vol. 3: 412 pp.

Decourt, J., L. P. Zonenshain, L. E. Ricou, V. G. Kazmin, X. L. Pichon, A. Knipper, C. Grandjacquet, I. Sbortshikov, J. Geyssant, C. Lepvrier, D. Pechersky, J. Boulin, J. Sibuet, L. Savostin, O. Sorokhtin, M. Westphal, M. Bazhenov, J. Lauer, and B. Biju-Duval. 1986. Geological evolution of the Thethys belt from the Atlantic to the Pamirs since the Lias. Tectonophysics 123(1-4):241-315.

Depéret, C. 1917. Monographie de la faune de mammifères fossiles du 
Ludien inférieur d'Euzet-les-Bains (Gard). Annales de l'Université de Lyon 1(40):1-290.

Estravis, C. 2000. Nuevos mamíferos del Eoceno Inferior de Silveirinha (Baixo Montego, Portugal). Coloquios de Paleontología 51:281-311.

Franzen, J. L. 1968. Revision der Gattung Palaeotherium Cuvier, 1804 (Palaeotheriidae, Perissodactyla, Mammalia). Ph.D. dissertation (unpublished). Albert-Ludwigs-Universität Freiburg, BadenWurtemberg, Germany, 181 pp.

Franzen, J. L. 1989. 7. Origin and systematic position of the Palaeotheriidae; pp. 102-108 in D. R. Prothero, and R. M. Schoch (eds.), The evolution of Perissodactyls. Oxford University Press, New York.

Froehlich, D. J. 1999. Phylogenetic Systematics of Basal Perissodactyls. Journal of Vertebrate Paleontology 19:140-159.

Gradstein, F. M., J. G. Ogg, A. G. Smith, F. P. Agterberg, W. Bleeker, R. A. Cooper, V. Davydov, P. Gibbard, L. Hinnov, M. R. House, L. Lourens, H.-P. Luterbacher, J. McArthur, M. J. Melchin, L. J. Robb, J. Shergold, M. Villeneuve, B. R. Wardlaw, J. Ali, H. Brinkhuis, F. J. Hilgen, J. J. Hooker, R. J. Howarth, A. H. Knoll, J. Laskar, S. Monechi, J. Powell, K. A. Plumb, I. Raffi, U. Röhl, A. Sanfilippo, B. Schmitz, N. J. Shackleton, G. A. Shields, H. Strauss, J. Van Dam, J. Veizer, Th. van Kolfschoten, and D. Wilson. 2004. A Geologic Time Scale 2004. Cambridge University Press, Cambridge, 500 pp.

Gray, J. E. 1821. On the natural arrangement of vertebrate animals. London Medical Repository 15:296-310.

Hartenberger, J. L. 1973. Les Rongeurs de l'Éocène d'Europe. Leur évolution dans leur cadre biogéographique. Bulletin du Muséum National d'Histoire Naturelle, $3^{\text {a }}$ serie, 132:49-70.

Hooker, J. J. 1992. British mammalian paleocommunities across the Eocene-Oligocene transition and their environmental implications; pp. $494-515$ in D. R. Prothero, W. A. Berggren (eds.), EoceneOligocene Climatic and Biotic Evolution. University of Princeton Press, Princeton, New Jersey.

Hooker, J. J. 1994. The beginning of the equoid radiation. Zoological Journal of the Linnean Society 112:29-63.

Hooker, J. J. 1998. Mammalian faunal change across the PaleoceneEocene transition; pp. 419-441 in M.-P Aubry, S. G Lucas, and W. A. Berggren (eds.), Late Paleocene-early Eocene Climatic and Biotic Events in the Marine and Terrestrial Records. Columbia University Press, Columbia.

Hooker, J. J., M. E. Collinson, and N. P. Sille. 2004. Eocene-Oligocene mammalian faunal turnover in the Hampshire Basin, UK: calibration to the global time scale and the major cooling event. Journal of the Geological Society, London 161:161-172.

Huerta, P., and I. Armenteros. 2006. Estratigrafía secuencial del Paleógeno de la cuenca de Almazán. Geo-Temas 9:121-124.

Iriarte, E., A. Badiola, J. M. Hernández, and A. Berreteaga. 2003. Sedimentología e interpretación paleoambiental de la sucesión con niveles de vertebrados fósiles del Eoceno Superior de Zambrana (Cuenca de Miranda-Treviño, Álava). Geogaceta 34:131-134.

Iriarte, E., A. Badiola, A. Berreteaga, and M. A. Cuesta. 2006. Sedimentología y datos preliminares sobre la diagénesis de los niveles con fósiles de vertebrados de Huérmeces del Cerro y Viana de Jadraque (Cuenca del Tajo, Guadalajara). Geo-Temas 9:131-135.

Jiménez, E. (ed.). 1992. Vertebrados fósiles de Castilla y León. Universidad de Salamanca (Museo de Salamanca), Salamanca, Castilla y León, $156 \mathrm{pp}$.

MacFadden, B. J. 1976. Cladistic analysis of primitive equids, with notes on other perissodactyls. Systematic Zoology 25:1-14.

Meulenkamp, J. E., W. Sissingh, J. V. Calvo, R. Daams, L. Londeix, B. Cahuzac, M. Kovac, A. Nagymarosy, D. Badescu, A. Rusu, B. Stu- dencka, V. N. Beniamovskii, I. G. Scherba, J. Roger, J.-P. Platel, F. Hirsch, A. Sadek, G. I. Abdel-Gawad, D. Zaghbib-Turki, K. Ben Ismail-Lattrache, S. Bouaziz, N. Karoui-Yaakoub, and C. Yaich. 2000. Map 17: Early to Middle Ypresian (55-51 Ma), Map 18: Late Lutetian (44-41 Ma). in J. Decourt, M. Gaetani, B. Vrielynck, E. Barrier, B. Biju-Duval, M. Brunet, J. P. Cadet, S. Crasquin, M. Sandukescu (eds.), 2000-Peri-Tethys: Paleogeographical maps. Paris, Commission de la carte Géologique du Monde (24 maps, scale $=1: 10.000 .000$ )

Owen, R. 1848. On the fossil remains of Mammalia referable to the genus Palaeotherium, and two genera Paloplotherium and Dichodon, hitherto undefined, from the Eocene Sand at Hordle, Hampshire. Quaternary Journal of the Geological Society of London 4:12-42.

Pavlow, M. 1887-1888. Études sur l'Histoire paléontologique des ongulés en Amérique et en Europe. Bulletin de la Société Impériale des Naturalistes de Moscou:1-80.

Peláez-Campomanes, P. 1993. Micromamíferos del Paleógeno Continental Español: Sistemática, Biocronología y Paleoecología. Ph.D. dissertation (unpublished). Universidad Complutense de Madrid, Madrid, Spain, 388 pp.

Pomel, A. 1847a. Note critique sur le genre Palaeotherium. Bulletin de la Société Géologique de France 2:584-587.

Pomel, A. 1847b. Notes sur les mammifères et reptiles fossiles des terrains éocènes de Paris, inférieurs au dépôt gypseux. Archives des Sciences Physiques et Naturelles de Genève 4:326-330.

Pomel, A. 1851. Nouvelles observations sur la structure des pieds dans les animaux de la famille des Anoplotherium et dans le genre Hyaemoschus. Comptes Rendus de l'Académie des Sciences, Paris 33:16.

Prothero, D. R. 1985. North American mammalian diversity and EoceneOligocene extinctions. Paleobiology 11:389-405.

Remy, J. A. 1965. Un nouveau genre de Paléothéridé (Perissodactyla) de l'Eocène supérieur du Midi de la France. Comptes Rendus de l'Académie des Sciences, Paris 260:4362-4364.

Remy, J. A. 1976. Étude comparative des structures dentaires chez les Palaeotheriidae et divers autres Périssodactyles fossiles. Ph.D. dissertation, Université de Strasbourg, Strasbourg 1(3), 207 pp.

Remy, J. A. 1998. Le genre Leptolophus (Perissodactyla, Mammalia): Morphologie et histologie dentaires, anatomie crânienne, implications fonctionnelles. Palaeovertebrata 27:45-108.

Remy, J. A. 2004. Le genre Plagiolophus (Palaeotheriidae, Perissodactyla, Mammalia): Revision systematique, morphologie et histologie dentaires, anatomie cranienne, essai d'interpretation fonctionnelle. Palaeovertebrata 33(1-4):1-275.

Schmidt-Kittler, N. (ed.). 1987. International Symposium on Mammalian Biostratigraphy and Paleoecology of the European Paleogene. Münchner Geowissenschaftliche Abhandlungen 10:1-311.

Schmidt-Kittler, N., and M. Vianey-Liaud. 1975. Les relations entre les faunes de rongeurs d'Allemagne du Sud et de France pendant l'Oligocène. Comptes Rendus de l'Académie des Sciences de Paris 281:511-514.

Stehlin, H. G. 1909. Remarques sur les faunules de Mammifères des couches éocènes et oligocènes du Bassin de Paris. Bulletin de la Société géologique de France 4(9):488-520.

Sudre, J. 1978. Les Artiodactyles de l'Eocène moyen et supérieur d'Europe occidentale: systématique et évolution. Mémoires et Travaux de l'Institut de Montpellier (EPHE) 7:1-229.

Vianey-Liaud, M. 1991. Les rongeurs de l'Eocène terminal et de l'Oligocène d'Europe comme indicateurs de leur environment. $\mathrm{Pa}$ laeogeography, Palaeoclimatology, Palaeoecology 85:15-28.

Submitted September 24, 2007; accepted March 21, 2008. 